\title{
Rezisztenciamódosítók összehasonlítása multidrog-rezisztens prosztata-, egérlymphoma- és vastagbélrák-sejtvonalakon
}

\author{
Csonka Ákos dr. \\ Szegedi Tudományegyetem, Általános Orvostudományi Kar, \\ Orvosi Mikrobiológiai és Immunbiológiai Intézet, Szeged
}

\begin{abstract}
Bevezetés: A kemoterápia sikertelenségének oka a tumorsejtek multidrog-rezisztenciájához köthető. Ezek közül az egyik legismertebb a membránban lokalizálódó efflux pumpák fokozott expressziója, például a P-glikoprotein jelenléte. Célkitüzés: A szerző a szubsztituált szteroid- és fenotiazinvegyületek antitumorhatását elemezte egér- és humán tumormodellekben in vitro. Módszer: A P-glikoprotein gátlását és az apoptózisindukciót áramlási citometriával jellemezte, illetve elemezte a doxorubicin és a vizsgált vegyületek közötti kölcsönhatást. A szteroidok és a P-glikoprotein közötti szerkezet-hatás összefüggést molekuláris docking vizsgálattal jellemezte. Eredmények: Az aminoacil-amid szubsztituensek jelenléte a szteroidvázon jelentős rákellenes hatást mutatott multidrog-rezisztens egérlymphoma- és prosztataráksejteken. A szteroidszármazékok többsége doxorubicinnel kombinálva potenciálja annak hatását hormonrezisztens humán prosztatarák-sejtvonalon. Az N-hidroxi-alkil-2-aminofenotiazin-származékok közül a másodlagos aminoknak volt tumorellenes hatása multidrog-rezisztens colonadenocarcinoma-sejteken. Következtetések: A vizsgált fenotiazinok és szubsztituált szteroidok antitumor-hatásúak, továbbá thioridazin esetében a sztereoizomériának nem volt szerepe a tumorsejtek gátlásában. Sem a szteroid, sem a thioridazin vegyületek nem mutattak apoptózist indukáló hatást hormonrezisztens humán prosztatarák-sejtvonalon. Orv. Hetil., 2016, 157(37), 1489-1495.
\end{abstract}

Kulcsszavak: szubsztituált szteroidok, fenotiazinok, multidrog-rezisztencia, ABCBl-transzporter, tumorsejtvonalak

\section{Comparison of the effect of multidrug resistance modifiers on prostate cancer, mouse lymphoma and colon cancer cells}

Introduction: The reason for unsuccessful tumor chemotherapy is related to multidrug resistance. An important factor is the overexpression of efflux pumps, such as P-glycoprotein. Aim: Amino- and amide-substituted steroid compounds and phenothiazine derivatives were investigated in tumor models in vitro. Method: The inhibition of P-glycoprotein was evaluated by flow cytometry and the interaction of these compounds with doxorubicin was investigated as well. Molecular docking was used to estimate the binding energies of the compounds to P-glycoprotein. Results: The aminosteroids showed anticancer activity on multidrug resistant mouse T-lymphoma and prostate cancer cell lines. The combination of steroids and doxorubicin potentiated its effect in hormone resistant prostate cancer cells. Among the $\mathrm{N}$-hydroxyalkyl-2-aminophenothiazines, secondary amines exhibited anticancer effects on multidrug resistant colon adenocarcinoma cells. Conclusions: The tested phenothiazine and steroid derivatives showed potent anticancer activity, furthermore, the stereoisomerism of thioridazine did not play a role in the antitumor properties. Neither steroids nor thioridazine influenced apoptosis in hormone resistant cells.

Keywords: substituted steroids, phenothiazines, multidrug resistance, $\mathrm{ABCB} 1$ transporter, cancer cell lines

Csonka, Á. [Comparison of the effect of multidrug resistance modifiers on prostate cancer, mouse lymphoma and colon cancer cells]. Orv. Hetil., 2016, 157(37), 1489-1495.

(Beérkezett: 2016. június 2.; elfogadva: 2016. június 30.) 


\section{Rövidítések}

ABC-transzporter $=($ ATP-binding cassette transporter $)$ ATPkötő kazettát tartalmazó transzporter; ATP = adenozin-trifoszfát; $\mathrm{BOC}=\mathrm{N}$-terc-butiloxikarbonil; $\mathrm{EU}=$ Európai Unió; FITC $=$ annexin V-fluoreszcein izotiocianát; $\mathrm{IC}_{50}=50 \%$-os gátlási koncentráció; $\mathrm{MDR}=$ multidrog-rezisztencia (több gyógyszerrel szemben kialakult rezisztencia); MTT = 3-(4,5-dimetil-tiazol-2-il)-2,5-difenil-bromid; PAR = L5178 egér-T-lymphoma szülői sejtvonal; P-gp = P-glikoprotein; Rl23 = rhodamin-123

A szív- és érrendszeri kórképek után a tumoros megbetegedések képezik a második leggyakoribb halálokot világszerte. A daganatok kialakulását a kontroll nélküli sejtproliferáció és a sejthalál hiánya jellemzi, amely abnormális sejtnövekedés, tumor kialakulásához vezet. A lokalizált tumorok elsődleges kezelési módja a mútét és a radioterápia, míg a metasztázist adók esetében a kemoterápia az elsődleges választás. A kemoterápia sikertelenségének oka a tumorsejtekben lévő multidrog-rezisztencia (MDR) mechanizmusaiban rejlik. Ezek közül az egyik legismertebb a membránban lokalizálódó különböző efflux pumpák fokozott expressziója. A tumorsejtekben ezek a transzporterfehérjék többféle, nem rokon szerkezetű rákellenes szert távolítanak el az intracelluláris térből, a flexibilis szubsztrátkötő helyüknek köszönhetően. Korunk egyik égető problémája olyan új, hatékony vegyületek kifejlesztése, amelyekkel képesek leszünk leküzdeni a tumorsejtek rezisztenciamechanizmusait.

\section{A prosztatarák, a lymphoproliferativ kórképek, illetve a vastag- és végbélrák morbiditási és mortalitási adatai}

A prosztatarák kialakulása összetett mechanizmus, a fó okok között szerepel a jelátviteli kaszkádok hibája, illetve a szerzett rezisztencia, amely következtében a programozott sejthalál elmarad. A várható élettartam növekedésével a prosztatarák előfordulása nő, és a rendelkezésre álló jobb diagnosztikai módszerek miatt korábban kerül felismerésre. Az EU-ban a prosztatarák a leggyakoribb rosszindulatú betegség a középkorú férfiak körében. Az elöregedő társadalomban a férfi lakosság halálozási aránya a prosztatarák miatt aránytalanul növekszik, és ennek az aggasztó tendenciának a magyarázata eddig még ismeretlen [1].

A lymphoproliferativ kórképek morbiditása és mortalitása is jelentős. Évente mintegy 450000 új beteget és 225000 halálesetet jelentenek világszerte. Ezek a betegségek meglehetősen heterogének, ́́gy pontos diagnosztikájukhoz a klinikai jellemzőkön és a klasszikus szövettani morfológián túl, az immunológiai fenotípus meghatározása, a citogenetikai és a molekuláris sajátosságok átfogó értékelése elengedhetetlen. Mindazonáltal az utóbbi időben korszerű és rendkívül pontos molekuláris bioló- giai technikákat fejlesztettek ki, amelyek elérhetővé váltak a laboratóriumi diagnosztika számára is. Többek között ezen módszerek közé tartoznak a microarray technikák és az új generációs szekvenálási eljárások, amelyek elősegítik a lymphomák heterogenitásának megértését, és elősegíthetik a bizonyos lymphomaaltípusok megismerését $[2,3]$.

A vastag- és végbélrák a harmadik leggyakoribb daganat, és a negyedik leggyakoribb halálok világszerte, ez megközelítőleg 1,2 millió új beteget és 600000 halálesetet jelent évente. Előfordulása 50 éves kor alatt alacsony, de az életkor növekedésével incidenciája jelentősen emelkedik. A fejlett országokban a diagnózis felállításakor az átlagéletkor körülbelül 70 év. A legnagyobb számú előfordulást Európából, Észak-Amerikából és Óceániából jelentették [4].

\section{A gyógyszer-rezisztencia jelentősége}

A gyógyszer-rezisztencia kialakulása egy kiválasztódási folyamat, amely során a heterogén tumormasszából a domináns klónok szelektálódnak. A legtöbb kemoterápiás szerre létrejövő rezisztencia a gyógyszerrel történő ismételt kezelésekkel is előidézhető. A gyógyszerrezisztencia fő mechanizmusai: intracelluláris gyógyszerkoncentráció csökkentése transzportfehérjék által, a kemoterápiás szer és a célmolekula kölcsönhatásának megváltozása, a celluláris javítómechanizmusok módosulása és az apoptózist szabályozó gének múködésében bekövetkező változások (1. ábra) [5].

\section{Az efflux pumpákhoz kapcsolódó rezisztencia tumorsejtekben}

A transzportmechanizmusok közül az egyik legismertebb a membránban lokalizálódó különböző típusú efflux pumpák fokozott kifejeződése. Az efflux pumpáknak fontos szerep jut a sejtek normális életmúködéseiben: tápanyagfelvétel, mérgező metabolitok és különböző anyagok kiválasztása, sejthomeosztázis fenntartása [6]. Ilyen efflux pumpák az ATP-kötő kazettát tartalmazó ABC-transzporterek, amelyek az egyik legnagyobb és legősibb fehérje-szupercsalád. Napjainkig több mint 200 olyan fehérjét azonosítottak, amelyek az ABC fehérjeszupercsalád tagjai és a multidrog-rezisztenciában (MDR) is szerepet játszanak. Az ABC-transzporterek transzmembrán glikoproteinek, amelyek elősegítik a szerkezetileg nem rokon vegyületek egyirányú transzlokációját a sejtmembránon keresztül, kihasználva az adenozin-trifoszfát (ATP) hidrolíziséből származó energiát [7] (2. ábra). Az ABC-transzportereket konzervált szerkezet és hatásmechanizmus jellemzi, amely a prokaryotákból megőrződött az eukaryotákban is. Az MDR-ABC fehérjék eliminálják a különböző anyagokat a sejtekből, beleértve mind az endo-, mind a xenobiotikumokat. Az MDR daganatsejtekben gyakran fellelhető az $A B C B 1$ - 


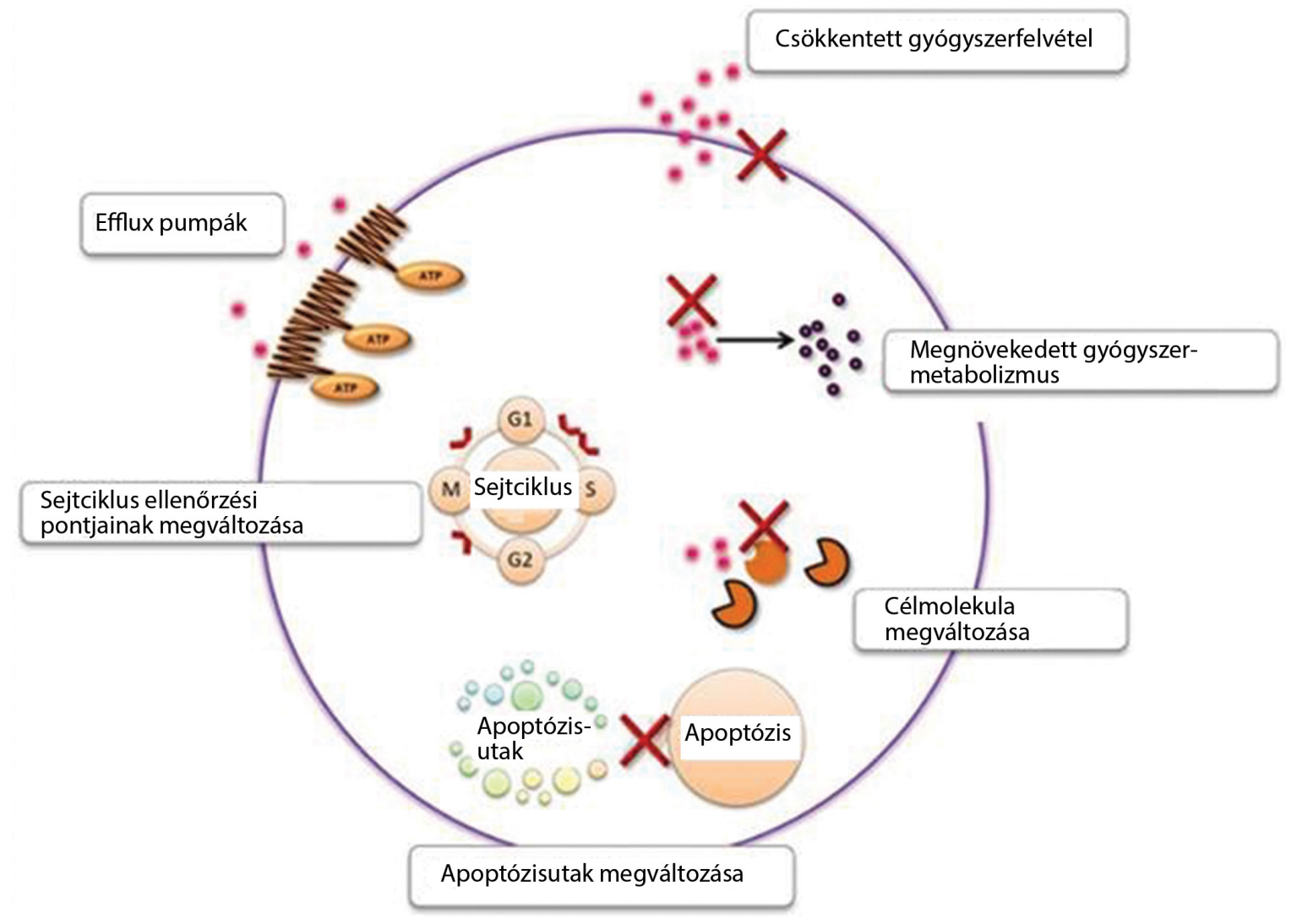

1. ábra

| A tumorsejtek drogrezisztenciájának fó mechanizmusai [5]

a

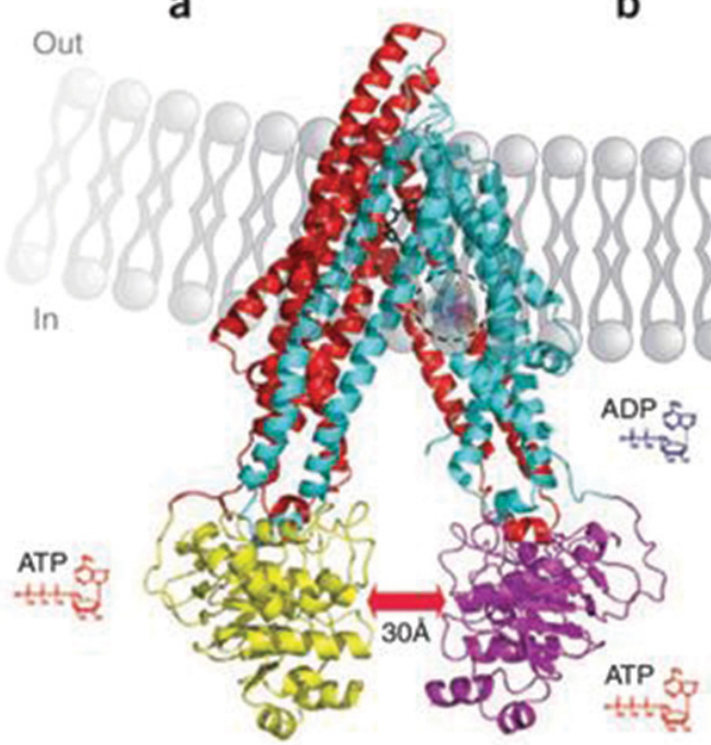

b

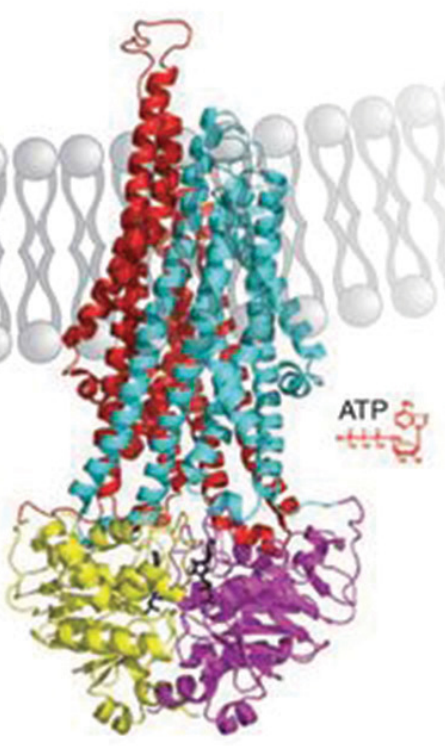

2. ábra

| ABC-transzporter sematikus szerkezete nyitott és zárt állapotban [7]

gén fokozott expressziója, amely a membránban lokalizált ABC-transzporter $\mathrm{Bl}$ fehérjét (ABCBl; P-glikoprotein) kódolja. $\mathrm{Az} A \mathrm{ABCBl}$ efflux pumpát a nagy transzportkapacitás és széles szubsztrátspecificitás jellemzi. Az általa transzportált molekulák általában hidrofób, amfipatikus, töltetlen vagy bázikus vegyületek, de esetenként negatív töltésűeket is képes eliminálni az intracelluláris térből. Megállapítható, hogy az ABCBl képes kölcsönhatásba lépni több mint 200 vegyülettel. Az ABCBl pumpa szubsztrátjai és modulátorai különböző kémiai szerkezetű csoportokba osztályozhatók. A legelterjedtebb megoldás, amely megváltoztatja az ABCBl 
múködését, a különböző inhibitorok használata. Napjainkig az ABCBl inhibitorok három generációját azonosították, amelyek lehetnek kompetitív és nem kompetitív inhibitorok. Ahogy az elnevezésük is szemlélteti, a kompetitív inhibitorok versenyeznek a citotoxikus szerek kötőhelyéért. Ha kapcsolódásuk sikeres az ABCBl efflux pumpához, a citotoxikus szer bejuthat a membránon keresztül az intracelluláris térbe. A nem kompetitív inhibitorok egy másik kötőhelyhez kapcsolódnak a fehérjemolekulán belül, így annak konformációja megváltozik, és ennek eredményeként a kemoterápiás szer képessé válik a sejtbe történő bejutásra [8-10]. Annak érdekében, hogy növeljük a már ismert kemoterápiás szerek hatékonyságát, amelyekre a tumorsejtek már rezisztenssé váltak, az efflux pumpák múködésére ható új vegyületek kifejlesztése lehet az egyik lehetőség.

\section{Célkitüzések}

Vizsgálataink elsődleges célja új perspektívák feltárása volt a kemoterápia során kialakuló multidrog-rezisztencia leküzdésére. Kísérleteink során szubsztituált szteroidok [11-13] és különböző fenotiazinszármazékok (3. ábra) között kerestünk nem toxikus, de hatékony vegyületeket az MDR gátlására [14, 15]. A vizsgált vegyületek MDR-gátló hatását már ismert kemoterapeutikumokkal kombinálva elemeztük különböző sejtvonalakon in vitro. Az apoptózist indukáló hatást és a tumorprogresszió gátlását egér-T-lymphoma- és a prosztatarák-sejtvonalakon vizsgáltuk. A vegyületek antiproliferatív hatását 3-(4,5-dimetil-tiazol-2-il)-2,5-difenilbromid (MTT) módszerrel vizsgáltuk L5178 egér-T-lymphoma szülői sejtvonalon (PAR), és humán $A B C B 1$-génnel transzfektált vonalán (MDR, L5178Y), LNCaP és PC3 prosztatarák-sejtvonalakon, valamint a multidrog-rezisztens Colo 320 vastagbéladenocarcinoma-sejtvonalon. A vegyületek citotoxikus hatását MTTmódszerrel vizsgáltuk PAR és MDR egér-T-lymphomasejtvonalakon. Kísérleteink során a szubsztituált szteroid- és thioridazinvegyületek ABCBl-moduláló hatását intracelluláris rhodamin-123- (R123) akkumulációval vizsgáltuk, áramlási citometria segítségével MDR

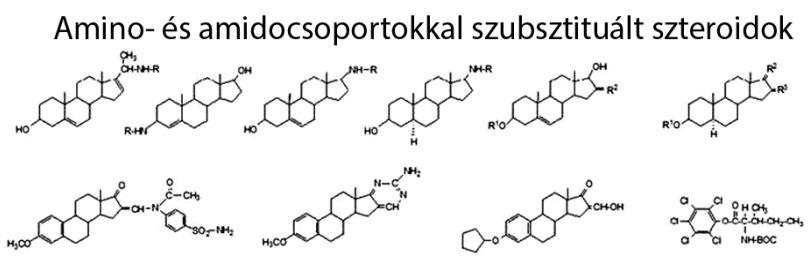

$N$-hidroxi-alkil-2-aminofenotiazin vegyületek

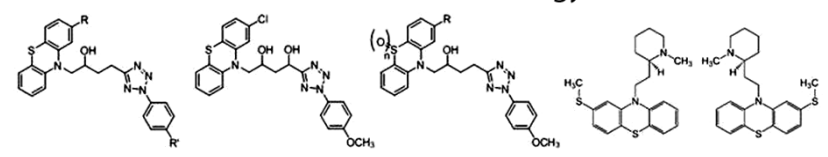

3. ábra $\quad$ A vizsgált vegyületcsoportok alapvázai
egér-T-lymphoma-sejtvonalon. Az ismert kemoterapeutikumok és a vizsgált szteroid- és $N$-hidroxi-alkil-2-aminofenotiazin-vegyületek kölcsönhatását 96 lyukas mikrotitráló lemezen vizsgáltuk PC3 és MDR Colo 320 sejtvonalakon. Az amino- és amidocsoportokkal szubsztituált szteroid- és a thioridazinvegyületek apoptózist indukáló hatását annexin V-fluoreszcein izotiocianát (FITC) módszerrel vizsgáltuk áramlási citometria segítségével, MDR egér-T-lymphoma- és PC3 prosztataráksejtvonalakon. A vegyületek szerkezetével összefüggő hatásokat a biológiai kísérletek alapján elemeztük molekuláris docking módszerrel. A mindennapi orvosi gyakorlatban különösen nagy figyelem fordul a gyógyszerek sztereoizomériai szerkezetéhez köthető biológiai hatások felé. Ennek szerepét vizsgáltuk a tumorellenes hatás tekintetében thioridazinvegyületek esetében.

\section{Eredmények}

\section{Antiproliferatí hatás vizsgálata}

A szubsztituált szteroidvegyületek közül az aminoacilamidsók és egy ösztron-éter származék mutattak jelentős antiproliferatív aktivitást ABCBl-et expresszáló MDR egér-T-lymphoma-sejtvonalon. Az aminoacilamidsók három különböző szteroidvázhoz (androsztán, androsztén és pregnándién) kapcsolódnak, míg az ösztron-éter származék egy kéttagú $\alpha$-hidroxi-metilén-keton elrendezést tartalmaz a D-gyưrűn, amely lehetővé teszi az 1,4-hidrogén donor-akceptor kapcsolatot. Másrészt a fent említett vegyületek hatékonynak bizonyultak az antiproliferatív vizsgálatokban hormonszenzitív LNCaP prosztatarák-sejtvonalon is.

A vizsgált $N$-hidroxi-alkil-2-aminofenotiazinok ígéretes antiproliferatív hatásúak az MDR vastagbéladenocarcinoma-sejtekben. Természetesen a szubsztituens csoportok markánsan befolyásolták a rákellenes aktivitást. A vegyületek szerkezete és aktivitása közötti kapcsolat elemzése során arra a következtetésre jutottunk, hogy a szekunder aminokkal szubsztituáltak (morfolin, dietilamin vagy $N$-metilpiperazin) az $N$-hidroxi-alkil-2-aminofenotiazin gyưrú 2 -es pozíciójában voltak a leginkább hatékonyak. Továbbá, az $\mathrm{IC}_{50}$-értékek alapján elmondható, hogy a kénatom oxidációs állapota (szulfoxid vagy szulfon) jelentős szerepet játszott az adott vegyület hatékonyságát illetően. Azok a vegyületek, amelyek a gyưrü 2 -es pozíciójában primer amint vagy savamidot tartalmaznak, kevésbé hatékonyak, mint a fent említett származékok. Az antiproliferatív vizsgálatok egyértelmüen bizonyítják, hogy a kén oxidációja vezetett a legaktívabb molekulák létrejöttéhez. Azt is megállapíthatjuk, hogy ez a szerkezeti változtatás egyértelmúen növelte a biológiai aktivitást.

A racém thioridazin és a (+) és (-) enantiomerjei között nem észleltünk szignifikáns különbséget az antiproliferatív aktivitás tekintetében MDR egér-T-lymphomaés PC3 prosztatarák-sejtvonalakon. 


\section{Citotoxicitás vizsgálata}

A szubsztituált szteroidszármazékok enyhe citotoxikus hatással rendelkeztek. Nem volt szignifikáns különbség a szülői és az MDR egér-T-lymphoma-sejtvonalon mutatott hatás között.

\section{Rhodamin-123-akkumuláció vizsgálata egér-T-lymphoma-sejtvonalon: ABCBI-gátlás vizsgálata}

A szubsztituált szteroidszármazékok hatását MDR-sejteken R123 intracelluláris akkumulációjának elemzésével vizsgáltuk, rövid inkubációs periódust és alacsony koncentrációt alkalmazva. Ebben a kísérletben $2 \times 10^{6}$ sejtet használtunk fel, a vizsgált vegyületeket $2 \mu \mathrm{g} / \mathrm{ml} \mathrm{kon}$ centrációban adtuk a mintákhoz, majd 10 perc inkubáció után Rl23-at adtunk a sejtekhez. Az aminoszteroidvegyületek, amelyek BOC aminosavakkal acilezettek, és az egyszerú $N$-acetil-származékok kifejezett aktivitást mutattak az MDR egér-T-lymphoma-sejtvonalon. A szabad aminocsoportokat tartalmazó szteroidok vagy aminhidroklorid-szubsztituensek bizonyítottan gyengébb vagy semmilyen aktivitást nem mutattak az $\mathrm{ABCB} 1$ gátlását tekintve.

A racém és a (+) és (-) thioridazin enantiomerek Rl23 intracelluláris akkumulációját MDR egér-T-lymphomasejtvonalon határoztuk meg. A thioridazin és enantiomerjei mérsékelten gátolták az $\mathrm{ABCB} 1$ aktivitását anélkül, hogy a sztereospecifitásuknak szerepe lett volna a hatást illetően.

\section{A rezisztenciamódositók és az ismert kemoterápiás szerek kombinációs vizsgálatának eredményei}

A szubsztituált szteroidvegyületek és a doxorubicin kombinációs vizsgálatokban mutatott aktivitása a hatástalantól az erős szinergizmusig változott. Nagyszámú szteroidszármazék fokozta a doxorubicin aktivitását PC3 sejtvonalon kombinációs kísérletekben. Az R123-vizsgálatban effektív $N$-hidroxi-alkil-2-aminofenotiazin-származékokat tanulmányoztuk kombinációs kísérletekben doxorubicinnel. Mindegyikük szinergista aktivitást mutatott doxorubicinnel a Colo 320 sejtvonalon. Az Nhidroxi-alkil-2-aminofenotiazin-származékok és a doxorubicin aránya ezekben a vizsgálatokban 12:1 volt. Feltételezhetó, hogy a hasonló szerkezeti elemek (szekunder amin a gyúrú 2-es pozíciójában, 2-hidroxicsoport az alkilláncban, szulfoxid vagy szulfon forma) felelős a vegyületek doxorubicinnel együtt tanúsított szinergizmusáért.

\section{A szubsztituált \\ szteroid-és a thioridazinvegyületek apoptózist indukáló hatása}

A szubsztituált szteroidvegyületek apoptózist indukáló hatását PC3 prosztatarák-sejtvonalon vizsgáltuk, nem toxikus koncentrációt alkalmazva. A vegyületeknek nem volt releváns apoptózist indukáló aktivitása; a korai apoptózis $1-6 \%$, a késői apoptózis és nekrózis $1-5 \%$ és a sejtpusztulás $1 \%$ körüli volt. Nem tapasztaltunk szignifikáns különbséget a kezeletlen kontrollal történő összehasonlítás során.

A thioridazin racém, (+) és (-) enantiomerek apoptózist indukáló hatását elemeztük MDR egér-T-lymphoma-sejtkultúrán. A thioridazin racém és (+) vagy (-) enantiomerjei között nem tapasztaltunk szignifikáns eltérést az apoptózist indukáló hatásban, ami arra enged következtetni, hogy a sztereoszelektivitás nem játszik szerepet az apoptózist indukáló hatásukban. Mind a racém thioridazin, mind az enantiomerjei korai apoptózist indukáltak PC3 sejtekben, de nem volt szignifikáns különbség a hatások között. Eredményeink egyértelmúen bizonyították, hogy a racém thioridazin és enantiomerjei lényegében azonos aktivitást produkálnak a replikáció és az apoptózisindukció tekintetében a különböző sejtvonalon.

\section{Molekuláris docking}

A molekuláris docking egy hatékony módszer, amely képes a kötési energia kiszámítására egy adott vegyület és egy fehérje között. A számítások alapján kimutatható az ideális fehérjekapcsolódási konfiguráció. Az algoritmus alapján előrevetíthető, hogy melyik aminosav vesz részt a hidrofób és a hidrogénkötések létrehozásában. A molekuláris docking eredmények azt mutatták, hogy a tesztelt vegyületek gátolják az ABCBl fehérje aktivitását, és azonos helyen kötődnek a fehérjéhez, mint a verapamil. A szubsztituált szteroidvegyületek és a P-glikoprotein (P-gp) közötti kölcsönhatást in silico vizsgálatokkal modelleztük, ahol a verapamilt mint pozitív kontrollt használtuk. Mindegyik szubsztituált szteroidvegyület alacsonyabb kötési energiával rendelkezett, mint a verapamil. A kötési energiák -6,43 és $-9,88 \mathrm{kcal} / \mathrm{ml}$ értékek között változtak. A gátlási állandók 0,1-10,1 M közötti értékek voltak.

\section{Megbeszélés}

Az aminoacilamidsókkal szubsztituált szteroidok hatékony sejtosztódást gátló aktivitást produkálnak az MDR egér-T-lymphoma- és LNCaP prosztatarák-sejtvonalakon, míg a primer aminocsoportot tartalmazó szteroidoknak nem volt hatásuk a prosztatarák-sejtvonalakon [16]. Nem találtunk szignifikáns különbséget a racém és 


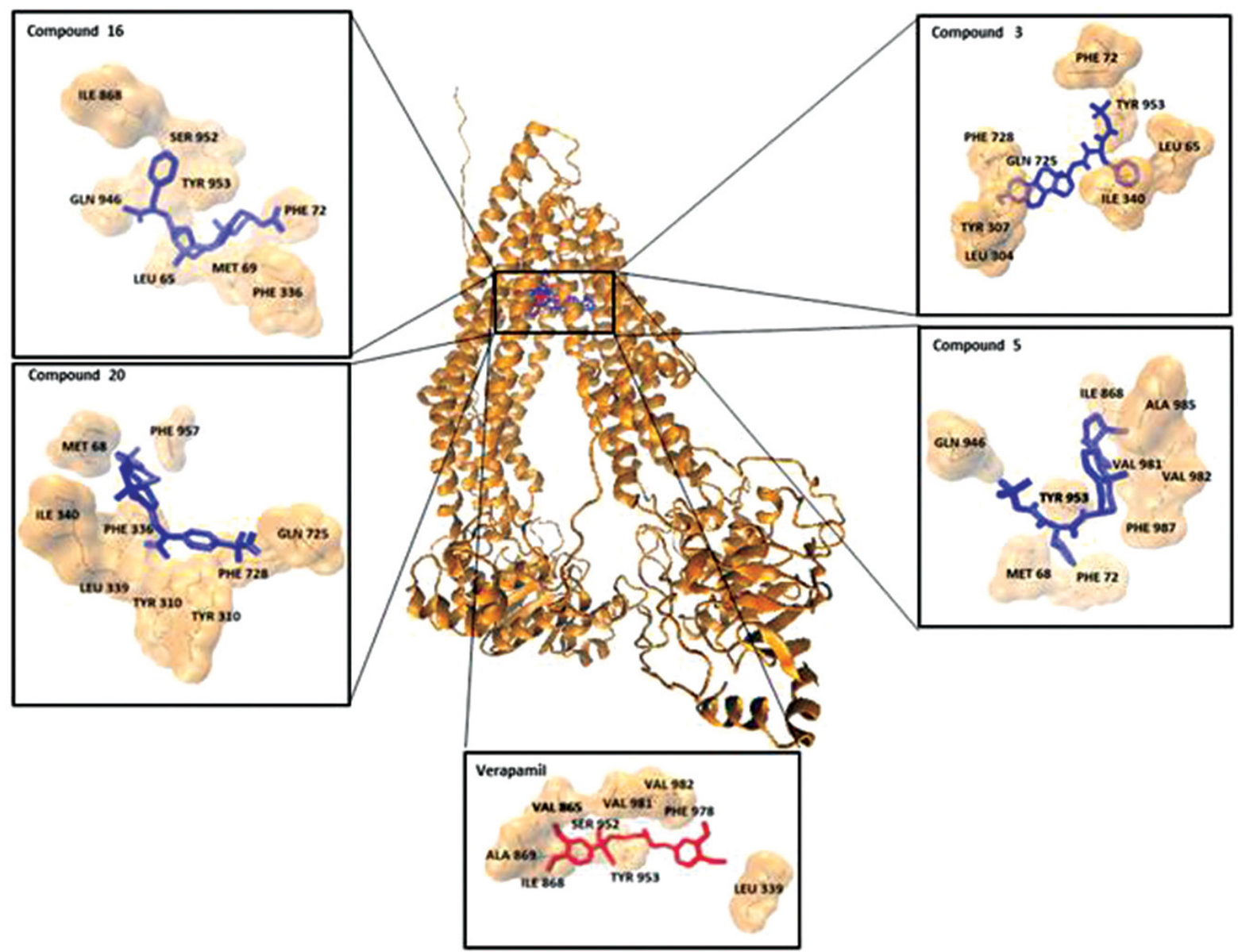

4. ábra $\quad$ A molekuláris docking vizsgálatokban leghatékonyabb vegyületek és a kontroll verapamil kötődési helye

a (+) és (-) thioridazin enantiomerek antiproliferatív aktivitása között MDR egér-T-lymphoma-sejtvonalon. Eredményeink alapján úgy túnik, az egy enantiomer önálló használata nem nyújt semmilyen előnyt az MDRtumorok elleni terápiában [17]. Az N-hidroxi-alkil2 -aminofenotiazinok esetében a gyưrü 2 -es pozíciójában lévő szekunder aminoknak, illetve a kénatom oxidációs állapotának (szulfoxid vagy szulfon) van szerepe a vegyületek antiproliferatív hatását illetően MDR vastagbéladenocarcinoma-sejtkultúrán. Nagyszámú szubsztituált szteroidvegyület fokozta a doxorubicin aktivitását kombinációs kísérletekben, PC3 prosztatarák-sejtvonalon. Az N-hidroxi-alkil-2-aminofenotiazinok esetében a doxorubicinnel való szinergizmust a gyürü 2 -es pozíciójában lévő szekunder aminok, a 2-hidroxi-csoport az alkilláncban, és a szulfoxid- vagy szulfoncsoport biztosítja [18]. Sem a szubsztituált szteroidok, sem a thioridazinszármazékok nem tudtak apoptózist indukálni PC3 prosztatarák vagy MDR egér-T-lymphoma-sejtvonalon [17, 19]. A molekuláris docking módszer segítségével meghatározható a kötési energia egy adott vegyület és egy fehérje között. A vizsgált szteroidvegyületek gátolták az ABCBl-aktivitást, és kötődési helyük megegyezett a verapamil kötődési helyével (4. ábra).
Anyagi támogatás: A közlemény megírása a Szegedi Rákkutatásért Alapítvány anyagi támogatásában részesült.

A szerző a cikk végleges változatát elolvasta és jóváhagyta.

Érdekeltségek: A szerzőnek nincsenek érdekeltségei.

\section{Irodalom}

[1] Ferlay, J., Steliarova-Foucher, E., Lortet-Tieulent, J., et al.: Cancer incidence and mortality patterns in Europe: Estimates for 40 countries in 2012. Eur. J. Cancer, 2013, 49(6), 1374-1403.

[2] Song, J. Y., Yu, J., Chan, W. C.: Gene expression profiling in nonHodgkin lymphomas. Cancer Treat. Res., 2015, 165, 97-123.

[3] Soldini, D., Campo, E.: New insights into the diagnosis of lymphomas. Ann. Oncol., 2012, 23(Suppl. 10), 83-88.

[4] Ferlay, J., Soerjomataram, I., Dikshit, R., et al.: Cancer incidence and mortality worldwide: sources, methods and major patterns in GLOBOCAN 2012. Int. J. Cancer, 2015, 136(5), E359E386.

[5] Chai, S., To, K. K., Lin, G.: Circumvention of multi-drug resistance of cancer cells by Chinese herbal medicines. Chin. Med., $2010,5,26$.

[6] Trimble, W. S., Grinstein, S.: Barriers to the free diffusion of proteins and lipids in the plasma membrane. J. Cell Biol., 2015, 208(3), 259-271. 
[7] Gottesman, M. M., Ambudkar, S. V., Xia, D.: Structure of a multidrug transporter. Nat. Biotechnol., 2009, 27(6), 546-547.

[8] Ling, V., Thompson, L. H.: Reduced permeability in CHO cells as a mechanism of resistance to colchicine. J. Cell Physiol., 1974, 83(1), 103-116.

[9] Maliepaard, M., van Gastelen, M. A., de Jong, L. A., et al.: Overexpression of the BCRP/MXR/ABCP gene in a topotecan-selected ovarian tumor cell line. Cancer Res., 1999, 59(18), 45594563.

[10] Davidson, A. L., Dassa, E., Orelle, C., et al.: Structure, function, and evolution of bacterial ATP-binding cassette systems. Microbiol. Mol. Biol. Rev., 2008, 72(2), 317-364.

[11] Szendi, Z., Dombi, G., Vincze, I.: Steroids, LIII: New routes to aminosteroids. Monatshefte für Chemie, 1996, 127(11), 11891196.

[12] Vincze, I., Hackler, L., Szendi, Z., et al.: Steroids 54. Amino acylamidosteroids. Steroids, 1996, 61(12), 697-702.

[13] Vincze, I., Somlai, Cs., Schneider, Gy., et al.: Steroids, XLV. Neighbouring group participation, XII. Decomposition of $(Z)$ 16-amidomethylene-17 $\beta$-hydroxysteroids mediated by neighbouring group participation. Liebigs Ann. Chem., 1992, 3, 187-192.

[14] Spengler, G., Takács, D., Horváth, A., et al.: Multidrug resistance reversing activity of newly developed phenothiazines on P-glycoprotein $(\mathrm{ABCB} 1)$-related resistance of mouse T-lymphoma cells. Anticancer Res., 2014, 34(4), 1737-1741.
[15] Takács, D., Egyed, O., Drahos, L., et al.: Synthesis and pharmacological investigation of new $\mathrm{N}$-hydroxyalkyl-2-aminophenothiazines exhibiting marked MDR inhibitory effect. Bioorg. Med. Chem., 2013, 21(13), 3760-3779.

[16] Csonka, Á., Hamdoun, S., Spengler, G., et al.: Substituted steroidal compounds containing amino and amido groups reverse multidrug resistance of mouse T-lymphoma and two human prostate cancer cell lines in vitro. Anticancer Res., 2015, 35(4), 2105-2112.

[17] Csonka, A., Spengler, G., Martins, A., et al.: Effect of thioridazine stereoisomers on the drug accumulation of mouse lymphoma and human prostate cancer cell lines in vitro. In Vivo, 2013, $27(6), 815-820$.

[18] Takács, D., Csonka, Á., Horváth, Á., et al.: Reversal of ABCBlrelated multidrug resistance of colonic adenocarcinoma cells by phenothiazines. Anticancer Res., 2015, 35(6), 3245-3251.

[19] Spengler, G., Molnar, J., Viveiros, M., et al.: Thioridazine induces apoptosis of multidrug-resistant mouse lymphoma cells transfected with the human $\mathrm{ABCBl}$ and inhibits the expression of Pglycoprotein. Anticancer Res., 2011, 31(12), 4201-4205.

(Csonka Ákos dr., Szeged, Semmelweis u. 6., 6725 e-mail: csonka.akos81@gmail.com)

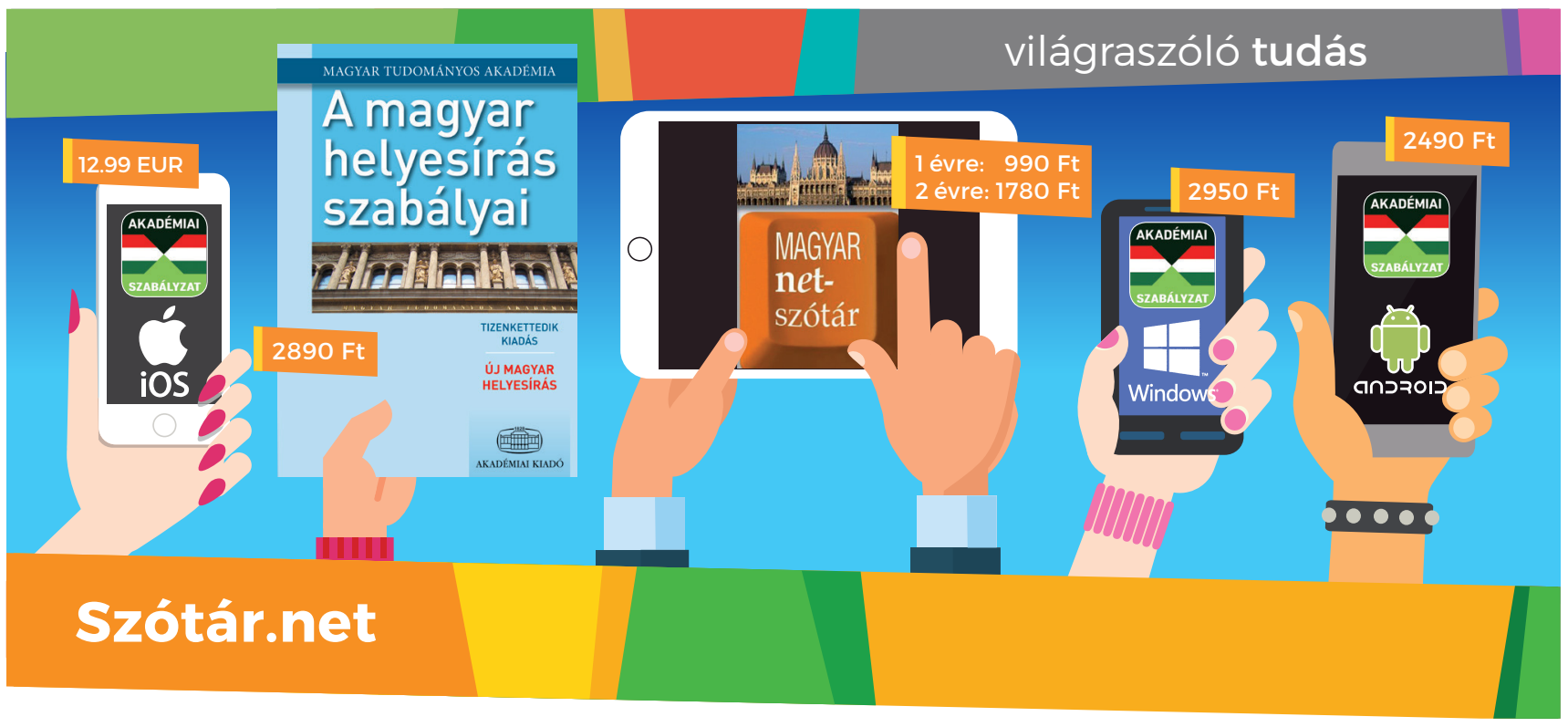

\section{A magyar helyesírás szabályai 12. kiadás Mindig a keze ůgyében!}

\section{- Magyar Tudományos Akadémia szabályzata - 300 szabálypont példákkal \\ - szabályzat és szótár egyben \\ • a 11. és a 12. kiadás közti különbségek felsorolása, példákkal \\ - tárgymutató}

Keresse a könyvet a www.akademiai.hu oldalon, vagy válassza az online változatot és a mobilalkalmazást a www.szotar.net-en!
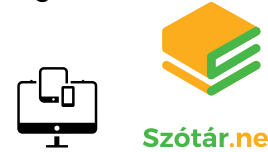

Szótár.net

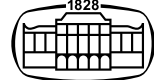

AKADÉMIAI KIADÓ 